\title{
Uteroplacental Insufficiency Alters Liver and Skeletal Muscle Branched-Chain Amino Acid Metabolism in Intrauterine Growth-Restricted Fetal Rats
}

\author{
JENNIFER L. KLOESZ, CYNTHIA M. SERDIKOFF, NICOLE K. MACLENNAN, \\ SIAMAK A. ADIBI, AND ROBERT H. LANE \\ Departments of Pediatrics [J.L.K.] and Medicine [C.M.S., S.A.A.], University of Pittsburgh School of \\ Medicine, Pittsburgh, PA 15213, U.S.A.; and Department of Pediatrics, Mattel Children's Hospital at \\ UCLA, UCLA School of Medicine, Los Angeles, CA 90095, U.S.A. [N.K.M., R.H.L]
}

\begin{abstract}
Uteroplacental insufficiency causes intrauterine growth restriction (IUGR) and decreases plasma levels of the branchedchain amino acids in both humans and rats. Increased fetal oxidation of these amino acids may contribute to their decline in the IUGR fetus. The rate-limiting step of branched-chain amino acid oxidation is performed by the mitochondrial enzyme branched-chain $\alpha$-keto acid dehydrogenase (BCKAD), which is regulated by a deactivating kinase. We therefore hypothesized that uteroplacental insufficiency increases BCKAD activity through altered mRNA and protein levels of BCKAD and/or the BCKAD kinase. In IUGR fetal liver, BCKAD activity was increased 3-fold, though no difference in hepatic BCKAD protein or mRNA levels were noted. Hepatic BCKAD kinase mRNA and protein levels were significantly decreased in association with the increase in BCKAD activity. In IUGR fetal skeletal muscle, BCKAD mRNA levels were significantly increased. IUGR skeletal muscle BCKAD protein levels as well as BCKAD kinase mRNA and protein levels were unchanged. We also quantified mRNA levels of two amino acid transporters: LAT1 (system L)
\end{abstract}

\section{ABSTRACT}

and $\mathrm{rBAT}$ (cysteine and dibasic amino acids). Both hepatic and muscle LAT1 mRNA levels were significantly increased in the IUGR fetus. We conclude that uteroplacental insufficiency significantly increases hepatic BCKAD activity in association with significantly decreased mRNA and protein levels of the deactivating kinase. We speculate that these changes contribute to the decreased serum levels of branched-chain amino acids seen in the IUGR fetus and may be an adaptation to the deprived milieu associated with uteroplacental insufficiency. (Pediatr Res 50: 604-610, 2001)
Abbreviations
IUGR, intrauterine growth restriction
BCAA, branched-chain amino acids
BCKAD, branched-chain $\alpha$-keto acid dehydrogenase
LAT1, system L amino acid transporter
rBAT, related to $\mathrm{b}$ system amino acid transporter
RT, reverse transcriptase

Uteroplacental insufficiency is a common and serious complication of pregnancy. It impairs the exchange of metabolites and gases between the mother and fetus, resulting in IUGR. In humans, the metabolic aberrations associated with the IUGR intrauterine milieu include decreased plasma concentrations of the BCAA: leucine, isoleucine, and valine (1-3). Similarly, Ogata et al. (4) found that uteroplacental insufficiency decreased serum BCAA levels in the IUGR fetal rat. Although decreased supply of the BCAA from the placenta contributes to

Received December 14, 2000; accepted July 17, 2001.

Correspondence and reprint requests: Robert H. Lane, M.D., Mattel Children's Hospital at UCLA, 10833 Le Conte Ave., B2-375 MDCC, Los Angeles, CA 90095-1752, U.S.A.; e-mail: rlane@mednet.ucla.edu

This work was supported by the Magee-Womens Hospital " 25 " Club, the MageeWomens Hospital Irene McLenahan Young Investigator Research Grant (J.L.K.), K08HD01225 (R.H.L.), and an American Diabetes Research Award (R.H.L.). the low plasma levels noted in the IUGR fetus, increased fetal utilization through increased mitochondrial oxidation may also play a role (5). Several investigators have noted that deprivation of the fetal sheep results in decreased serum levels of leucine and increased fetal leucine oxidation (6-8).

Irreversible oxidative decarboxylation of the BCAA is performed by the mitochondrial enzyme BCKAD (9). BCKAD is an enzyme complex composed of four subunits: $\mathrm{E} 1 \alpha, \mathrm{E} 1 \beta, \mathrm{E} 2$, and E3. Whereas the first three subunits are specific for BCKAD, the E3 subunit is common among the three keto-acid dehydrogenase complexes (BCKAD, pyruvate dehydrogenase, and $\alpha$-ketoglutarate dehydrogenase). BCKAD activity often correlates with mRNA and protein levels, though covalent modification through phosphorylation and dephosphorylation of the E1 $\alpha$ subunit determines physiologic activity (10-13). 
Phosphorylation (deactivation) of the enzyme is mediated by BCKAD kinase and dephosphorylation (activation) of the enzyme is mediated by a phosphatase. The kinase has been well characterized, but a rat-specific phosphatase has not yet been identified by either amino acid or nucleotide sequence.

Both the liver and skeletal muscle contribute to the total mitochondrial oxidative capacity of the BCAA in both humans and rats, and uteroplacental insufficiency alters mRNA, protein, and function of multiple mitochondrial enzymes in the fetal liver and skeletal muscle (14-17). We therefore hypothesized that BCKAD activity, mRNA, and protein levels would be increased in the liver and skeletal muscle of IUGR rat pups. To test our hypothesis, we performed bilateral uterine artery ligation on pregnant Sprague-Dawley rats to induce uteroplacental insufficiency and subsequent growth restriction. Fetal rats in this well-characterized model are significantly lighter than controls that undergo identical anesthesia and sham surgery, and litter size does not differ between control and IUGR groups $(4,15-21)$. BCKAD activity was subsequently measured in fetal liver with a radiochemical assay. Fetal liver and skeletal muscle BCKAD protein mass and mRNA levels were then determined with Western blotting and RT-PCR. The same methods were used to measure BCKAD kinase protein and mRNA levels in fetal liver and skeletal muscle.

In addition, we measured mRNA levels of two amino acid transporters using the same fetal tissues. LAT1 is a system L amino acid transporter that is co-expressed with the heavy chain of the 4F2 antigen $(22,23)$. The BCAA are significant substrates for LAT1 (24). rBAT is a system b amino acid transporter; substrates for rBAT include cysteine and the dibasic amino acids (25). Increased expression of amino acid transporters may facilitate increased transport of their substrates into specific tissues for use in metabolic processes. We hypothesized that mRNA levels of LAT1 but not rBAT would be increased in IUGR fetal liver and skeletal muscle.

\section{METHODS}

Tissue preparation. These studies were approved by the Institutional Animal Care and Use Committee of the MageeWomens Hospital Research Institute, Pittsburgh, PA, U.S.A.

Bilateral uterine artery ligation of the pregnant SpragueDawley rat was used to induce IUGR as described previously (15-21, 26). Litter size does not significantly differ between sham and IUGR groups and IUGR pups are significantly smaller at birth (IUGR average weight $2.69 \pm 0.47 \mathrm{~g}$, sham average weight $3.2 \pm 0.63 \mathrm{~g}$ ). Briefly, on d 19 of gestation, pregnant rats were anesthetized with intraperitoneal xylazine ( 8 $\mathrm{mg} / \mathrm{kg}$ ) and ketamine $(40 \mathrm{mg} / \mathrm{kg})$, the peritoneal cavity was exposed, and both uterine arteries were identified and ligated with silk suture ( $n=11$ litters). The procedure was identical for sham (control) animals except for ligation ( $n=9$ litters). Rats recovered within a few hours and had ad libitum access to food and water. On d 21 of gestation (term), the fetuses were delivered by cesarean section, weighed, and decapitated. The fetal livers and hindlimb skeletal muscle were harvested immediately and frozen in liquid nitrogen. Two to three livers and five to eight pairs of hindlimb skeletal muscle were pooled (for an $n=1)$ to determine enzyme activity, protein mass, and mRNA levels.

Extraction of BCKAD. BCKAD complex was extracted from the fetal livers and skeletal muscle by a method of homogenization adapted by this lab from the method described for extraction of BCKAD from adult rat tissue (27). The use of homogenates, rather than mitochondrial fractions, allows easier sample preparation and thus the ability to analyze the larger number of physically small samples available from fetal rat tissue (28). Briefly, 150-350 mg of fetal liver were homogenized in nine volumes of homogenization buffer $(0.25 \mathrm{M}$ sucrose, $50 \mathrm{mM}$ Tris- $\mathrm{HCl}$, and $2 \mathrm{mM}$ EDTA, at $\mathrm{pH}$ 7.4) with a Ducell glass homogenizer. This homogenate was used as the source of BCKAD activity. A cytosolic enzyme, $\alpha$-ketoisocaproate oxidase, will interfere with the liver assay if $\alpha$-keto $\left[1-{ }^{14} \mathrm{C}\right]$ isocaproate is used as the substrate (29). Therefore, activity had to be determined in the cytosolic fraction as well as in the whole tissue homogenate. The cytosolic fraction was prepared by centrifuging a portion of the whole tissue homogenate at $2000 \times g$ for $10 \mathrm{~min}$ at $4^{\circ} \mathrm{C}$. The supernatant was then centrifuged further at $10,000 \times g$ for $15 \mathrm{~min}$ at $4^{\circ} \mathrm{C}$. The resulting supernatant was the cytosolic fraction.

Similarly, 350-1000 $\mathrm{mg}$ of fetal skeletal muscle were homogenized in three volumes of Chappell-Perry medium (100 $\mathrm{mM} \mathrm{KCl}, 5 \mathrm{mM} \mathrm{MgSO}{ }_{4}, 1 \mathrm{mM}$ ATP, $1 \mathrm{mM}$ EDTA, $50 \mathrm{mM}$ Tris- $\mathrm{HCl}$, at $\mathrm{pH}$ 7.4) with a Polytron homogenizer. The homogenate was then centrifuged at $500 \times g$ for $10 \mathrm{~min}$ at $4^{\circ} \mathrm{C}$ to separate out cartilage and bone fragments and the resulting supernatant was used as the source of BCKAD complex.

Protein concentration. Protein concentrations for extracted liver and skeletal muscle BCKAD complex were determined by the Bio-Rad (Richmond, CA) protein assay using BSA as the standard.

$\boldsymbol{B C K A D}$ activity. Activity of extracted liver BCKAD was determined radiochemically by measuring the release of ${ }^{14} \mathrm{CO}_{2}$ from $\alpha$-keto $\left[1-{ }^{14} \mathrm{C}\right]$ isocaproate (30). The complete assay mixture contained (final volume $1 \mathrm{~mL}$ ): $2 \mathrm{mM} \mathrm{NAD}^{+}, 0.5 \mathrm{mM}$ CoA, $0.5 \mathrm{mM}$ TPP, $2 \mathrm{mM}$ DTT, $30 \mathrm{mM} \mathrm{KPO}_{4}, 0.2 \mathrm{mM}$ EDTA, $20 \mu \mathrm{g} / \mathrm{mL}$ leupeptin, $1 \mathrm{mM}$ TLCK, $2 \mathrm{mg} / \mathrm{mL} \mathrm{W}$-1 detergent, 5 $\mathrm{mM} \mathrm{MgSO} 4,0.2 \mathrm{mM} \alpha$-keto $\left[1-{ }^{14} \mathrm{C}\right]$ isocaproate $(2500 \mathrm{dpm} /$ $\mathrm{nmol})$, and appropriate amounts of BCKAD (0.25-1.5 $\mathrm{mg}$ of protein). All assays were done in triplicate at $37^{\circ} \mathrm{C}$ and the reaction was carried out for $15 \mathrm{~min}$. At the end of this period, the reaction was stopped with $500 \mu \mathrm{L}$ of $5 \mathrm{~N} \mathrm{H}_{2} \mathrm{SO}_{4}(14), \mathrm{CO}_{2}$ was collected in hydroxide of hyamine, and radioactivity was determined by liquid scintillation spectrometry. Enzyme activity was calculated as nmole of $\mathrm{CO}_{2}$ released per minute per milligram of protein. Activities were determined in both the cytosolic and whole tissue homogenate fractions. The cytosolic activity was subtracted from the whole tissue homogenate activity to give the activity of BCKAD in the sample. Because of small tissue sample size and relatively low activity compared with liver, reliable measurements of BCKAD activity in fetal skeletal muscle were not attainable.

Activity state of BCKAD. Covalent modification through phosphorylation and de-phosphorylation determines BCKAD activity. Basal activity is a measure of enzyme activity based upon this phosphorylation status, and total activity is a measure 
of enzyme activity regardless of BCKAD phosphorylation status. In brief, the activity state in the liver was determined by measuring BCKAD activity before (basal activity) and after (total activity) treatment of the extracted enzyme complex with a broad specificity phosphoprotein phosphatase (25 milliunits of phosphatase/mg protein incubated with $15 \mathrm{mM} \mathrm{MgSO}_{4}$ and $0.1 \mathrm{mM} \alpha$-chloroisocaproate in extraction buffer for $30 \mathrm{~min}$ at $37^{\circ} \mathrm{C}$ ). The phosphoprotein phosphatase was purified from rat liver as previously described (31). The activity state is then expressed as the ratio of basal activity to total activity.

Protein levels of BCKAD and BCKAD kinase. Identical amounts $(100 \mu \mathrm{g})$ of extracted liver and skeletal muscle protein were suspended in $4 \times$ SDS gel-loading buffer $(0.125 \mathrm{M}$ Tris$\mathrm{HCl}$ at $\mathrm{pH} 6.8,20 \%$ glycerol, $4 \% \mathrm{SDS}, 10 \% \beta$-mercaptoethanol, and $0.5 \%$ bromophenol blue) and boiled for $90 \mathrm{~s}$. Samples were then subjected to SDS $/ 10 \%$ PAGE in the system of Laemmli (32). Resolved proteins were transferred onto nitrocellulose membranes (Hybond ECL; Amersham, Arlington Heights, IL). Ponceau S staining of the nitrocellulose membranes was used to standardize protein loading before Western blotting. In brief, the nitrocellulose membranes were incubated for 5-10 min with a 1:10 dilution of Ponceau S stain (2 g Ponceau S, $30 \mathrm{~g}$ trichloroacetic acid, $30 \mathrm{~g}$ sulfosalicylic acid, and $\mathrm{dH}_{2} \mathrm{O}$ to $100 \mathrm{~mL}$ ). Once the bands appeared, the membranes were washed several times with $\mathrm{dH}_{2} \mathrm{O}$ and then subjected to densitometry using Scion Image PC. Membranes were then incubated either with polyclonal antibody $(1: 2000)$ raised against purified BCKAD complex or polyclonal antibody (1:500) raised against purified BCKAD kinase. The membranes were then washed and incubated with a second antibody (peroxidase-conjugated goat anti-rabbit $\operatorname{IgG}$ ), 1:5000 for BCKAD or 1:2000 for BCKAD kinase as described previously (33). BCKAD subunits and BCKAD kinase were detected with the ECL Western blotting system (Amersham, Arlington Heights, IL). The intensity of the bands was quantified by densitometry using Scion Image PC.

$\boldsymbol{R N A}$ isolation. Total RNA was extracted from the harvested livers and skeletal muscle by the method of Chomczynski and Sacchi and quantified in triplicate using UV absorbance at 260 $\mathrm{nm}$ (34). Gel electrophoresis confirmed integrity of the samples. Bovine retinal RNA was prepared in a similar manner.

mRNA levels (RT-PCR) of BCKAD and BCKAD kinase. This methodology of RT-PCR has been previously described $(16-18,20,35)$. cDNA was synthesized using random hexamers and SUPERSCRIPT II RT (Life Technologies, Gaithersburg, MD, U.S.A.) from $1.0 \mu \mathrm{g}$ of rat liver or skeletal muscle RNA added to $0.01 \mu \mathrm{g}$ of bovine retinal RNA. The resulting cDNA was resuspended in $20 \mu \mathrm{L}$ of water, diluted into $1: 100$ aliquots, and stored at $-20^{\circ} \mathrm{C}$ until use.
The amplification primers for BCKAD subunits E1 $\alpha$ and E1 $\beta$, BCKAD kinase, LAT1, and rBAT are listed in Table 1. To determine reaction conditions when both amplicons were simultaneously produced exponentially, serial dilutions of rat RNA with standard amounts of retinal RNA were reverse transcribed and amplified under different conditions and cycle numbers. Once optimal conditions were determined, a single standard serial dilution was run with each quantification to regularly verify parallel production of both rat and bovine PCR products. Reactions were replicated three times once optimal PCR conditions were determined, and the primer concentrations were identical between study groups (sham and IUGR).

The PCR products were separated on a nondenaturing $5 \%$ acrylamide gel, and the radioactivity incorporated into the amplified product was quantified using a phosphorimager and Molecular Analyst software (Bio-Rad Laboratories, Hercules, CA). The abundances of each target were quantified relative to that of a control rhodopsin band from the same reaction, which was assigned an arbitrary level of unity. To determine the specificity of the primers, the amplified products were sequenced.

Statistics. All data are presented as mean \pm SEM. The $t$ test was used for statistical analysis of all data except RT-PCR. For RT-PCR, statistical analyses were performed using the nonparametric Wilcoxon matched pair test.

\section{RESULTS}

BCKAD activity. Basal BCKAD activity, which is dependent upon the phosphorylation status of the enzyme, was increased 4-fold in the IUGR fetal liver compared with the sham fetal liver [IUGR $=2.24 \pm 0.81 \mathrm{nmol} / \mathrm{min} / \mathrm{mg}$ protein $(p<0.05)$, sham $=0.57 \pm 0.14 \mathrm{nmol} / \mathrm{min} / \mathrm{mg}$ protein, $n=6]$ (Table 2). Uteroplacental insufficiency, however, did not significantly change the total activity of BCKAD, which is not dependent upon the phosphorylation status of the enzyme, resulting in a higher activity state of BCKAD in the IUGR fetal liver $[$ IUGR $=18.00 \pm 2.71 \%(p<0.05)$, sham $=5.36 \pm$ $1.55 \%, n=6]$ (Table 2). That is, although the total activity of the enzyme did not change significantly, the proportion of active (or dephosphorylated) enzyme was significantly increased in the IUGR fetal liver.

Protein mass of BCKAD. The protein mass of BCKAD subunits $\mathrm{E} 1 \alpha, \mathrm{E} 1 \beta$, and $\mathrm{E} 2$ did not differ significantly between sham and IUGR fetal liver $(n=6)$ (Fig. 1A). Similarly, no significant difference was noted in the protein mass of any of the BCKAD subunits between sham and IUGR fetal skeletal muscle $(n=5)$ (Fig. $1 B)$.

Table 1. Sequences of PCR primers

\begin{tabular}{lllcc}
\hline Gene & \multicolumn{1}{c}{ Sense primer $\left(5^{\prime}-3^{\prime}\right)$} & \multicolumn{1}{c}{ Antisense primer $\left(3^{\prime}-5^{\prime}\right)$} & $\begin{array}{c}\text { Size of PCR } \\
\text { product }(\mathrm{bp})\end{array}$ & Accession No. \\
\hline E1 $\alpha$ & TGGCTACGCAGATCCCTCAG & CCTCAATGAGGAAGGGCTGG & 357 & J02827 \\
E1 $\beta$ & CAACGAAGCTGCCAAGTATCG & TGGACCTGTTCCACTGCTG & 273 & M94040.1 \\
Kinase & CGATCAAGGACCAGGCAGAC & ACGAGTCGAGATGATGCCAAC & 250 & M93271.1 \\
LAT1 & CATCATTGGCCTCCTCAC & TAGTAGCACGCAGAGGCAGGC & 129 & ABO15432 \\
rBAT & TTCCGGGCATACTGTGTACG & GAGAAGTCAGCCGAGAAGTC & 109 & M77345 \\
\hline
\end{tabular}


Table 2. Liver BCKAD activity

\begin{tabular}{clcc}
\hline & Basal activity & Total activity & Activity state \\
\hline Sham & $0.57 \pm 0.14$ & $19.68 \pm 6.79$ & $5.36 \pm 1.55$ \\
IUGR & $2.24 \pm 0.81^{*}$ & $13.83 \pm 4.66$ & $18.00 \pm 2.71^{*}$ \\
\hline
\end{tabular}

Activities expressed as $\mathrm{nmol} / \mathrm{min} / \mathrm{mg}$ protein, $n=6, * p<0.05$.

A)

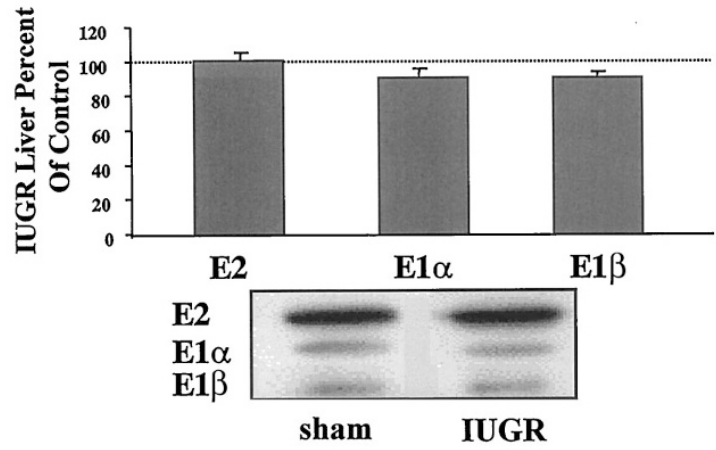

B)

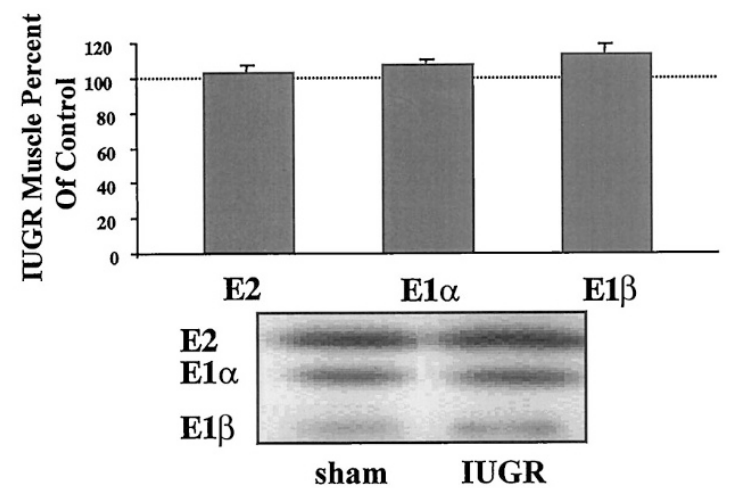

Figure 1. (A) Representative Western blot and quantification of BCKAD subunits $\mathrm{E}_{2}, \mathrm{E}_{1 \alpha}$, and $\mathrm{E}_{1 \beta}$ in sham and IUGR fetal liver $(n=6)$. (B) Representative Western blot and quantification of BCKAD subunits $\mathrm{E}_{2}, \mathrm{E}_{1 \alpha}$, and $\mathrm{E}_{1 \beta}$ in sham and IUGR fetal skeletal muscle $(n=5)$. Protein was quantified by densitometry using Scion Image PC. Results are expressed as mean percentage \pm SEM relative to the mean of the sham values

mRNA levels of BCKAD. Quantitative densitometric analysis of the RT-PCR products for BCKAD subunits E1 $\alpha$ and E1 $\beta$ demonstrated no significant difference in mRNA levels of BCKAD between sham and IUGR fetal liver $(n=6)$ (Fig. $2 A)$. However, in fetal skeletal muscle, mRNA levels for IUGR BCKAD subunits $\mathrm{E} 1 \alpha$ and $\mathrm{E} 1 \beta$ were significantly greater than sham mRNA levels (IUGR E1 $\alpha=344 \pm 43 \%$ sham, IUGR $\mathrm{E} 1 \beta=250 \pm 49 \%$ sham, $p<0.05, n=8$ ) (Fig. $2 B$ ).

Protein mass of BCKAD kinase. BCKAD kinase protein mass was $16 \%$ lower in IUGR fetal liver compared with sham fetal liver (IUGR $=84.2 \pm 3.8 \%$ sham, $p<0.05, n=6$ ) (Fig. $3 A$ ). Interestingly, no significant difference was found in the protein mass of BCKAD kinase between IUGR and sham fetal skeletal muscle $(n=5)$ (Fig. $3 B)$.

mRNA levels of BCKAD kinase. Similarly, mRNA levels of BCKAD kinase were $35 \%$ lower in IUGR fetal liver compared with sham fetal liver (IUGR $=65 \pm 9 \%$ sham, $p<0.05, n=$ 8) (Fig. 4A), whereas mRNA levels of BCKAD kinase were not significantly different for IUGR and sham fetal skeletal muscle $(n=8)$ (Fig. 4B).
A)

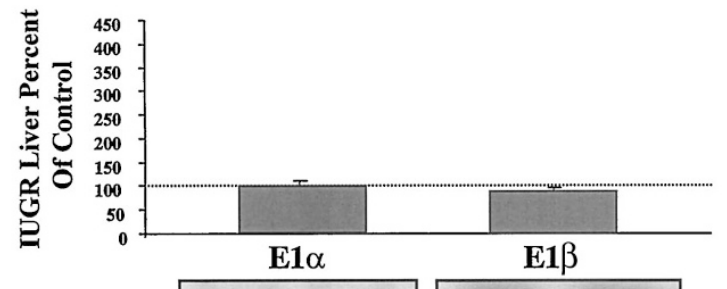

B)
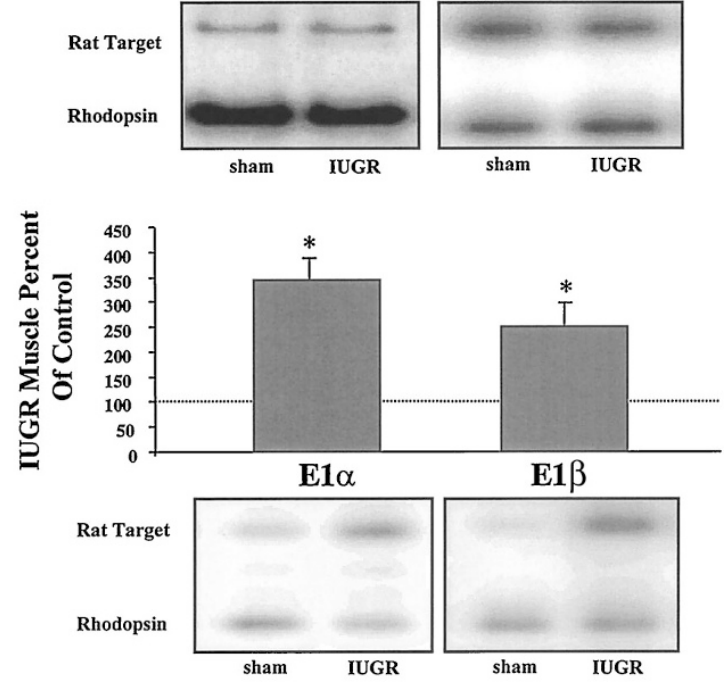

Figure 2. (A) Representative phosphorimage and quantification of BCKAD subunits $\mathrm{E}_{1 \alpha}$ and $\mathrm{E}_{1 \beta}$ RT-PCR products in sham and IUGR fetal liver $(n=6)$. (B) Representative phosphorimage and quantification of BCKAD subunits $\mathrm{E}_{1 \alpha}$ and $\mathrm{E}_{1 \beta}$ RT-PCR products in sham and IUGR fetal skeletal muscle $(n=8)$. RT-PCR products were quantified by phosphorimage analysis using Molecular Analyst software (Bio-Rad). Results are expressed as mean percentage \pm SEM relative to the mean of the sham values. ${ }^{*} p<0.05$ vs sham.

mRNA levels of LAT1 and rBAT. LAT1 mRNA levels were significantly increased in IUGR fetal liver compared with sham fetal liver (IUGR $=230 \pm 27 \%$ sham, $p<0.05, n=8$ ) (Fig. $5 A$ ). mRNA levels of LAT1 were also significantly increased in IUGR fetal skeletal muscle (IUGR LAT1 $=137 \pm 9 \%$ sham, $p<0.05, n=8$ ) (Fig. 5B). rBAT mRNA levels showed no significant difference between IUGR and sham fetuses for either liver or skeletal muscle $(n=8)$ (Fig. 5, $A$ and $B)$.

\section{DISCUSSION}

The results of the current study demonstrate that uteroplacental insufficiency causes an increase in hepatic BCKAD activity through a 3-fold increase in the enzyme's activity state. This increase in BCKAD activity is associated with decreased mRNA and protein levels of the deactivating kinase. These novel findings suggest a molecular mechanism by which fetal hepatic oxidation contributes to the decreased plasma levels of the BCAA previously found in the IUGR fetal rat.

A trend does exist toward decreased hepatic protein levels of the $\mathrm{E} 1 \alpha$ and the $\mathrm{E} 1 \beta$ subunit as well as total hepatic activity. These findings may reflect the effects of the deprived IUGR intrauterine milieu experienced by the fetus and subsequent reduction in hepatic protein synthesis; however, the decrease seems to be compensated for by the post-translational covalent modification of dephosphorylation as demonstrated by the increase in BCKAD basal activity and activity state. 
A)

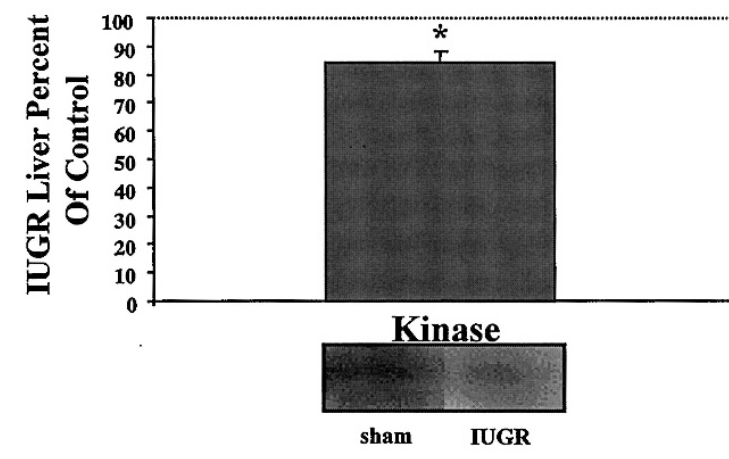

B)

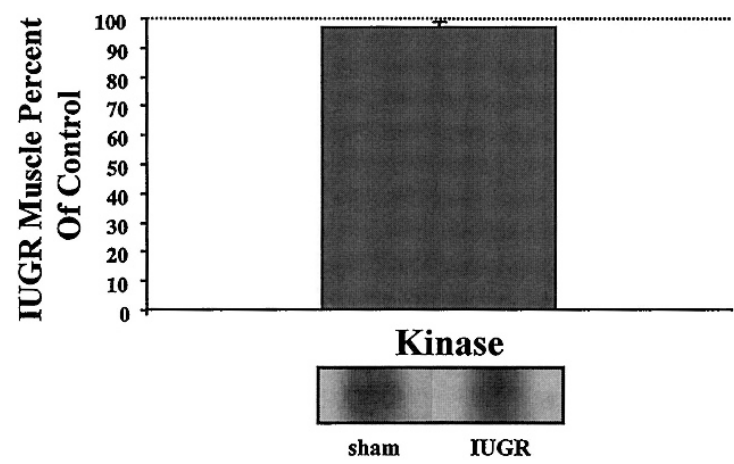

Figure 3. (A) Representative Western blot and quantification of BCKAD kinase in sham and IUGR fetal liver $(n=6)$. (B) Representative Western blot and quantification of BCKAD kinase in sham and IUGR fetal skeletal muscle $(n=5)$. Protein was quantified by densitometry using Scion Image PC. Results are expressed as mean percentage \pm SEM relative to the mean of the sham values. ${ }^{*} p<0.05$ vs sham.

Human studies on BCAA metabolism in the IUGR fetus report a decline in the fetal/maternal leucine ratio that correlates with the severity of growth restriction and reflects reduced transplacental leucine flux and/or increased protein breakdown within the fetoplacental compartments (5). Previous animal studies on BCAA metabolism and fetal deprivation have used sheep models to measure maternal-placental-fetal leucine flux and utilization. In a model of heat stress-induced IUGR, maternal-placental leucine flux is reduced and leucine is subsequently redirected toward fetal metabolism via decreased placental utilization and decreased leucine flux from the fetus to the placenta (36). Maternal starvation of pregnant ewes elevates fetal leucine oxidation, which is inversely correlated with fetal glucose concentration $(7,9)$. Although both of these studies provide important physiologic insight, neither approach the organ-specific molecular biology behind their findings.

The molecular and biochemical characteristics of BCKAD have been documented in adult rats. Whereas restricting protein intake in adult animals results in decreased hepatic activity of the enzyme, subsequent fasting of these experimental animals results in increased activation of BCKAD (12). Moreover, hepatic BCKAD activity increases in response to metabolic acidosis and correlates indirectly with hepatic ATP concentrations $(37,38)$. Although caution must be exercised when applying the results of adult studies to fetal metabolism, our findings of increased BCKAD activation correlate with the known biochemistry of the complex because previous studies
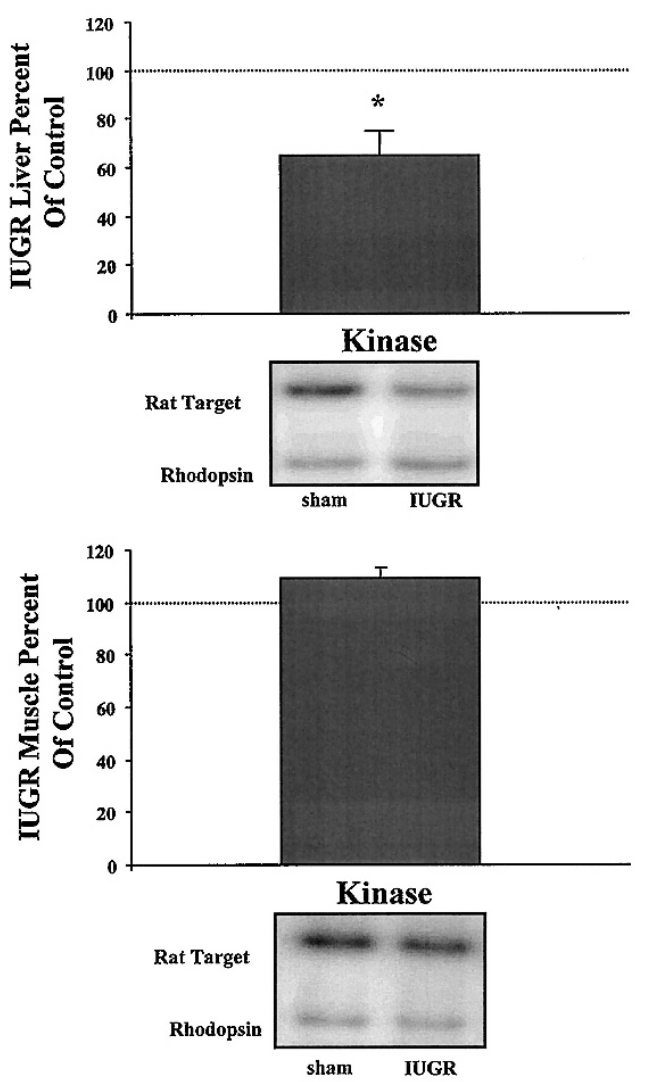

Figure 4. $(A)$ Representative phosphorimage and quantification of BCKAD kinase RT-PCR products in sham and IUGR fetal liver $(n=8)$. ( $B$ ) Representative phosphorimage and quantification of BCKAD kinase RT-PCR products in sham and IUGR fetal skeletal muscle $(n=8)$. RT-PCR products were quantified by phosphorimage analysis using Molecular Analyst software (Bio$\mathrm{Rad})$. Results are expressed as mean percentage \pm SEM relative to the mean of the sham values. ${ }^{*} p<0.05$ vs sham.

of our model of uteroplacental insufficiency and IUGR demonstrate acidosis and reduced levels of hepatic ATP $(4,19)$.

One possible problem with our study concerns the relatively low-activity state of BCKAD noted in both the sham and IUGR fetal livers. Previous studies have reported hepatic BCKAD activity states of nearly $100 \%$ in neonatal rat pups $<12 \mathrm{~h}$ old $(39,40)$. However, our study focuses on fetal rat pups, which differ from neonatal rat pups in several ways. Unlike neonatal rat pups, our animals have not gone through the process of labor and birth with all its attendant changes in maternal and fetal hormone and catecholamine levels. In addition, our animals have never had a breast milk feeding, which would be expected to alter overall energy metabolism in the neonate. All of these factors must be considered when evaluating the differences seen between fetal and neonatal hepatic BCKAD activity state.

Of interest, several other models analogous to ours have demonstrated significantly lower activity states for hepatic BCKAD. In fetal sheep, BCKAD was found to be only $50 \%$ active whereas in protein-starved adult rats the enzyme's activity state was noted to be even lower at $33 \%(31,41)$. Even more impressive were reports of BCKAD activity state as low as $9 \%$ in adult female rats fed a low-protein diet (42). This low-activity state was secondary to increased kinase activity 


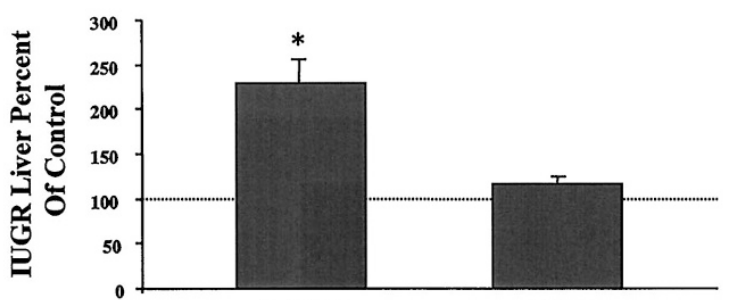

A)

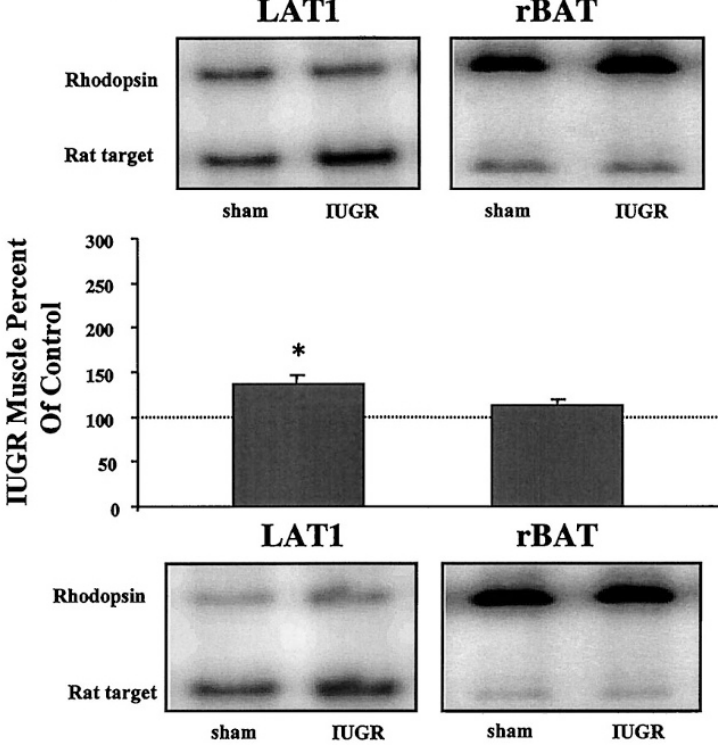

Figure 5. (A) Representative phosphorimage and quantification of LAT1 and rBAT RT-PCR products in sham and IUGR fetal liver $(n=8)$. (B) Representative phosphorimage and quantification of LAT1 and rBAT RT-PCR products in sham and IUGR fetal skeletal muscle $(n=8)$. RT-PCR products were quantified by phosphorimage analysis using Molecular Analyst software (Bio$\mathrm{Rad})$. Results are expressed as mean percentage \pm SEM relative to the mean of the sham values. ${ }^{*} p<0.05 v s$ sham.

and represented a major gender difference in BCKAD activity state. This gender difference may reflect the effects of different hormones on BCKAD activation. We thus speculate that the lower BCKAD activity state seen in fetal rats compared with neonatal rat pups may be due not only to the lack of the effects of labor, birth, and breast milk feedings, but also may reflect the influences of maternal hormones while the pups are still in utero.

Uteroplacental insufficiency in the rat fetus is also characterized by hypoxia, and fetal oxygen consumption is significantly affected by insulin secretion (43). Leucine is an important insulin secretagogue (44). We speculate that increased hepatic BCKAD activity may be an adaptive measure undertaken by the IUGR fetus to lower fetal leucine levels and thus fetal oxygen consumption.

A significant increase in BCKAD mRNA levels in IUGR skeletal muscle was also noted. Although these results suggest that BCKAD mRNA levels are increased in IUGR skeletal muscle, protein mass of BCKAD was not found to be significantly increased in the same tissue. Perhaps the changes in protein levels are lagging behind the changes in mRNA in anticipation of delivery. Further studies might be directed toward determining BCKAD protein mass and mRNA levels in neonatal IUGR liver and skeletal muscle.
In adult animals, skeletal muscle significantly contributes BCAA metabolism, including oxidation, though little is known about fetal skeletal muscle BCAA metabolism. One study, by Singh et al. (45), demonstrated that acetate and $\alpha$-ketoacids account for only $12 \%$ of hindlimb oxygen consumption, whereas in contrast, these substrates account of $48 \%$ of oxygen consumption in maternal hindlimb. Unfortunately, because of small tissue sample size and relatively low activity compared with liver, reliable measurements of BCKAD activity in fetal skeletal muscle were not attainable. Our findings are similar to that of Veerkamp and Wagenmakers (39) who measured actual and total BCKAD activity in postnatal rat tissues and were unable to detect either total or actual activity in skeletal muscle until ten days of life. Similarly, when Goodwin et al. (41) measured BCKAD activity in fetal sheep tissues, they found that skeletal muscle total and actual activity were decreased to $<10 \%$ of hepatic values.

A significant increase in mRNA levels of the amino acid transporter LAT1 was seen in both the liver and skeletal muscle of IUGR fetuses. However, no significant difference in mRNA levels of the amino acid transporter rBAT was seen in either IUGR liver or skeletal muscle. The BCAA are significant substrates for LAT1, whereas substrates for rBAT include cysteine and the dibasic amino acids. Increased expression of the amino acid transporters may facilitate increased transport of their substrates into specific tissues for use in metabolic processes. The increased mRNA levels of LAT1 noted in IUGR liver and skeletal muscle may thus indicate increased transport of the BCAA into these tissues, thus increasing availability of these substrates for oxidation by BCKAD. The lack of a similar increase in mRNA levels of rBAT in IUGR liver and skeletal muscle suggests that this adaptation is specific for those transporters associated with the BCAA.

Caution is necessary of course when attempting to apply data from a rat model to human pathophysiology. The fetal and juvenile rat is physiologically immature relative to the human, and the insult imposed on the fetal rat in this model of uteroplacental insufficiency is severe and specific. In contrast, the timing and impact of uteroplacental insufficiency experienced by humans range across a continuum.

In summary, uteroplacental insufficiency causes an increase in BCKAD activity in fetal IUGR rat liver that is associated with decreased mRNA and protein levels of the deactivating kinase for BCKAD. Increased hepatic oxidation of the BCAA may contribute to the decreased plasma levels of the BCAA observed in the IUGR fetus. In addition, increased liver BCKAD activity may be an effective metabolic adaptation that contributes to increased survival of the IUGR fetus.

Acknowledgments. The authors thank Dr. Sherin Devaskar and Dr. Jon Watchko for their support, guidance and review of this manuscript. We also thank Jennifer Hsu and Tho Pham for their enthusiasm and hard work.

\section{REFERENCES}

1. Cetin I, Marconi AM, Bozzetti P, Sereni LP, Corbetta C, Pardi G, Battaglia FC 1988 Umbilical amino acid concentrations in appropriate and small for gestational age infants: a biochemical difference present in utero. Am J Obstet Gynecol 158:120-126 
2. Cetin I, Marconi AM, Corbetta C, Lanfranchi A, Baggiani AM, Battaglia FC, Pardi G 1992 Fetal amino acids in normal pregnancies and in pregnancies complicated by intrauterine growth retardation. Early Hum Dev 29:183-186

3. Karsdop VH, van Vugt JM, Jakobs C, Dekker GA, van Geijn HP 1994 Amino acids, glucose, and lactate concentrations in umbilical cord blood in relation to umbilical artery flow patterns. Eur J Obstet Gynecol Reprod Biol 57:117-122

4. Ogata ES, Bussey ME, Finley S 1986 Altered gas exchange, limited glucose and branched chain amino acids, and hypoinsulinism retard fetal growth in the rat. Metabolism 35:970-977

5. Marconi AM, Paolini CL, Stramare L, Cetin I, Fennessey PV, Pardi G, Battaglia FC 1999 Steady state maternal-fetal leucine enrichments in normal and intrauterine growth-restricted pregnancies. Pediatr Res 46:114-119

6. Carver TD, Quick AA, Teng CC, Pike AW, Fennessey PV, Hay WW Jr 1997 Leucine metabolism in chronically hypoglycemic hypoinsulinemic growth restricted fetal sheep. Am J Physiol 272:E107-E117

7. Liechty EA, Denne SC, Lemmon JA, Kien CL 1991 Effects of glucose infusion on leucine transamination and oxidation in the ovine fetus. Pediatr Res 30:423-429

8. van Veen LC, Teng C, Hay WW Jr, Meschia G, Battaglia FC 1987 Leucine disposal and oxidation rates in the fetal lamb. Metabolism 36:48-53

9. Harper AE, Miller RH, Block KP 1984 Branched-chain amino acid metabolism. Annu Rev Nutr 4:409-454

10. Fatania HR, Laus KS, Randle PJ 1981 Inactivation of purified ox kidney branchedchain-2-oxoacid dehydrogenase by phosphorylation. FEBS Lett 132:285-288

11. Paxton R, Harris RA 1982 Isolation of rabbit liver branched chain alpha-ketoacid dehydrogenase and regulation by phosphorylation. J Biol Chem 257:14433-14439

12. Harris RA, Powel SM, Paxton R, Gillim SE, Nagae H 1985 Physiological covalent regulation of rat liver branched chain $\alpha$-ketoacid dehydrogenase. Arch Biochem Biophys 243:542-555

13. Lombardo YB, Thamotharan M, Bawani SZ, Paul HS, Adibi SA 1997 Post transcriptional alterations in protein masses of hepatic branched-chain keto acid dehydrogenase and its associated kinase in diabetes. Proc Assoc Am Physicians 110:40-49

14. Suryawan A, Hawes JW, Harris RA, Shimomura Y, Jenkins AE, Hutson SM 1998 A molecular model of human branched-chain amino acid metabolism. Am J Clin Nutr $68: 72-81$

15. Lane RH, Flozak AS, Ogata ES, Bell GI, Simmons RA 1996 Altered hepatic gene expression of enzymes involved in energy metabolism in the growth-retarded fetal rat. Pediatr Res 39:390-394

16. Lane RH, Chandorkar AK, Flozak AS, Simmons RA 1998 Intrauterine growth retardation alters mitochondrial gene expression and function in fetal and juvenile rat skeletal muscle. Pediatr Res 43:563-570

17. Lane RH, Kelley DE, Gruetzmacher EM, Devaskar SU 2001 Uteroplacental insufficiency alters hepatic fatty acid metabolizing enzymes in juvenile and adult rats. Am J Physiol 280:R183-R190

18. Lane RH, Crawford SE, Flozak AS, Simmons RA 1999 Localization and quantifications of glucose transporters in liver of small for gestational age fetal and neonatal rats. Am J Physiol 276:E135-E142

19. Ogata ES, Swanson SL, Collins JW, Finley SL 1990 Intrauterine growth retardation: altered hepatic energy and redox states in the fetal rat. Pediatr Res 27:56-63

20. Lane RH, Kelley DE, Ritov VH, Tsirka AE, Gruetzmacher EM 2001 Altered expression and function of the trifunctional protein of $\beta$-oxidation in juvenile IUGR rats. Pediatr Res 50:83-90

21. Das UG, Sadiq HF, Soares MJ, Hay WW, Devaskar SU 1998 Time-dependent physiological regulation of rodent and ovine placental glucose transporter (GLUT-1) protein. 274:R339-R347

22. Estevez R, Camps M, Rojas AM, Testar X, Deves R, Hediger MA, Zorzano A, Palacin M 1998 The amino acid transport system $\mathrm{y}+\mathrm{L} / 4 \mathrm{~F} 2 \mathrm{hc}$ is a heteromultimeric complex. FASEB J 12:1319-1329

23. Torrents D, Estevez R, Pineda M, Fernandez E, Lloberas J, Shi YB, Zorzano A Palacin M 1998 Identification and characterization of a membrane protein $(y+L$ amino acid transporter-1) that associates with $4 \mathrm{~F} 2 \mathrm{hc}$ to encode the amino acid transport activity y+L. J Biol Chem 273:32437-32445
24. Kanai Y, Segawa H, Miyamoto K, Uchino H, Takeda E, Endou H 1998 Expression cloning and characterization of a transporter for large neutral amino acids activated by the heavy chain of 4F2hc antigen (CD98). J Biol Chem 273:23629-23632

25. Palacin M 1994 A new family of proteins (rBAT and 4F2hc) involved in cationic and zwitterionic amino acid transport: a tale of two proteins in search of a transport function. J Exp Biol 196:123-137

26. Ogata ES, Swanson SL, Collins JW Jr, Finley SL 1990 Intrauterine growth retardation: altered hepatic energy and redox states in the fetal rat. Pediatr Res 27:56-63

27. Goodwin GW, Zhang B, Paxton R, Harris RA 1988 Determination of activity and activity state of branched-chain $\alpha$-keto acid dehydrogenase in rat tissues. Methods Enzymol 166:189-201

28. Block KP, Aftring RP, Buse MG, Harper AE 1988 Estimation of branched-chain $\alpha$-keto acid dehydrogenase activation in mammalian tissues. Methods Enzymol 166:210-213

29. Sabourin PJ, Bieber LL 1982 Purification and characterization of an alphaketoisocaproate oxygenase of rat liver. J Biol Chem 257:7460-7467

30. Paul HS, Adibi SA 1982 Activation of hepatic branched chain $\alpha$-keto acid dehydrogenase by a skeletal muscle factor. J Biol Chem 257:12581-12588

31. Gillim SE, Paxton R, Cook GA, Harris RA 1983 Activity state of the branched chain $\alpha$-ketoacid dehydrogenase complex in heart, liver, and kidney of normal, fasted, diabetic, and protein-starved rats. Biochem Biophys Res Commun 111:74-81

32. Laemmli UK 1970 Cleavage of structural proteins during the assembly of the head of bacteriophage T4. Nature 227:680-685

33. Paul HS, Liu W, Adibi SA 1996 Alteration in gene expression of branched-chain keto acid dehydrogenase kinase but not in gene expression of its substrate in the liver of clofibrate-treated rats. Biochem J 317:411-417

34. Chomczynski P, Sacchi N 1987 Single step method of RNA isolation by acid guanidinium thio-cyanate-phenol-chloroform extraction. Anal Biochem 162:156-159

35. Lane RH, Flozak AS, Simmons RA 1996 Measurement of GLUT mRNA in liver of fetal and neonatal rats using a method of quantitative polymerase chain reaction. Biochem Mol Med 59:192-199

36. Ross JC, Fennessey PV, Wilkening RB, Battaglia FC, Meschia G 1996 Placental transport and fetal utilization of leucine in a model of fetal growth retardation. Am J Physiol 270:E491-E503

37. Rodriguez-Bayona B, Peragon J 1998 Stimulation of rat-liver branched-chain alphaketo acid dehydrogenase activity by chronic metabolic acidosis. Int J Biochem Cell Biol 30:529-534

38. Paul HS, Adibi SA 1982 Role of ATP in the regulation of branched-chain alpha-keto acid dehydrogenase activity in liver and muscle mitochondria of fed, fasted and diabetic rats. J Biol Chem 257:4875-4881

39. Veerkamp JH, Wagenmakers AJM 1987 Postnatal development of the actual and total activity of the branched-chain 2-oxo acid dehydrogenase complex in rat tissues. Int J Biochem 19:205-207

40. Zhao Y, Denne SC, Harris RA 1993 Developmental pattern of branched-chain 2-oxo acid dehydrogenase complex in rat liver and heart. Biochem J 290:395-399

41. Goodwin GW. Gibboney W, Paxton R, Harris RA, Lemons JA 1987 Activities of branched-chain amino acid aminotransferase and branched-chain 2-oxo acid dehydrogenase complex in tissues of maternal and fetal sheep. Biochem J 242:305-308

42. Kobayashi R, Shimomura Y, Murakami T, Nakai N, Fujitsuka N, Otsuka M, Arakawa N, Popov KM, Harris RA 1997 Gender differences in regulation of branched-chain amino acid catabolism. Biochem J 327:449-453

43. Stonestreet BS 1990 Effects of prolonged fetal hyperinsulinemia on plasma catecholamines, circulation and oxygen metabolism in utero. Dev Pharmacol Ther $15: 34-44$

44. Rhoten WB 1980 Insulin secretory dynamics during development of rat pancreas. Am J Physiol 239:E57-E63

45. Singh S, Sparks JW, Meschia G, Battaglia FC, Makowski EL 1984 Comparison of fetal and maternal hind limb metabolic quotients in sheep. Am J Obstet Gynecol 149:441-449 